\title{
Bionomics of Melipona mondury Smith 1863 (Hymenoptera: Apidae, Meliponini) in relation to its nesting behavior
}

\author{
Jaqueline Lemos Viana ${ }^{1}$, Henrique de Abreu Cerqueira Sousa ${ }^{I}$, Rogério Marcos de Oliveira Alves ${ }^{2}$, \\ Derval Gomes Pereira ${ }^{I}$, Juvenal Cordeiro Silva Jr. ${ }^{1}$, Joana Fidelis da Paixão ${ }^{2,3}$ \& Ana Maria Waldschmidt \\ ${ }^{1}$ Universidade Estadual do Sudoeste da Bahia, Jequié, BA, Brazil. \\ ${ }^{2}$ Instituto Federal de Educação, Ciência e Tecnologia Baiano, Catu, BA, Brazil. \\ ${ }^{3}$ Corresponding author: Joana Fidelis da Paixão, e-mail: joana.paixao@ifbaiano.edu.br
}

VIANA, J.L., SOUSA, H.A.C., ALVES, R.M.O., PEREIRA, D.G., SILVA J.R., J.C., PAIXÃO, J.F., WALDSCHMIDT, A.M. Bionomics of Melipona mondury Smith 1863 (Hymenoptera: Apidae, Meliponini) in relation to its nesting behavior. Biota Neotropica. 15(3): e20140097. http://dx.doi.org/10. 1590/1676-06032015009714

\begin{abstract}
Melipona mondury Smith 1863 is an important stingless bee species pollinator and honey/pollen producer, but threatened by fragmentation of habitats throughout its range. This article presents the identification and partial characterization of nesting substrates, bionomic including population features of $M$. mondury by comparing data between nest architecture of natural beehive and boxes colonies. Nineteen colonies (13 in boxes and six in beehives) were analyzed with regards to substrate nesting, nest characteristics (e.g. length and width of the combs, height and diameter of the pollen and honey jar) and bee population. The average volume and diameter of the trunks cavities used for nesting of M.mondury were $18.4 \mathrm{~L}$ and $15.8 \mathrm{~cm}$; the average number of combs was 9.26; the average diameter and height of the honey pots were $2.81 \mathrm{~cm}$ and $3.29 \mathrm{~cm}$, and the average volume of honey stored was $15.85 \mathrm{~mL}$; the average height and diameter of pollen pots was $3.21 \mathrm{~cm}$ and $2.93 \mathrm{~cm}$, respectively, while the average mass of pollen deposited was equal to $12.56 \mathrm{~g}$. The population ranged from 3537 to 10281 individuals between colonies. The results suggest that the conservation of $M$. mondury should involve reforestation with native species from Atlantic Forest, and the dimensions of boxes should be based on the average size of the nests in the natural environment in order to support strategies of conservation and sustainable management of this species.
\end{abstract}

Keywords: Conservation, nest architecture, nesting substrate, rational management, stingless bees.

VIANA, J.L., SOUSA, H.A.C., ALVES, R.M.O., PEREIRA, D.G., SILVA J.R., J.C., PAIXÃO, J.F., WALDSCHMIDT, A.M. Bionomia de Melipona mondury Smith 1863 (Hymenoptera: Apidae, Meliponini) em relação ao seu comportamento de nidificação. Biota Neotropica. 15(3): e20140097. http:// dx.doi.org/10.1590/1676-06032015009714

Resumo: Melipona mondury Smith 1863 é uma espécie de abelha sem ferrão, importante polinizadora, produtora de mel e de pólen, mas ameaçada pela fragmentação dos habitats ao longo de sua área de ocorrência. Este artigo apresenta a identificação e a caracterização parcial dos substratos de nidificação e as características bionômicas, incluindo as populacionais, de $M$. mondury, comparando os dados de arquitetura do ninho entre colônias de cortiço e caixas rústicas. Dezenove colônias (13 em caixas rústicas e seis em cortiços) foram analisadas em relação aos substratos de nidificação, características do ninho (e.g.: comprimento e largura dos favos de cria, altura e diâmetro dos potes de pólen e mel) e população das abelhas. Foram encontrados volume e diâmetro médios da cavidade dos troncos nidificados por M. mondury, de 18,4 L e 15,8 cm; número médio de favos de cria de 9,26; diâmetro e altura médios dos potes de mel de $2,81 \mathrm{~cm}$ e $3,29 \mathrm{~cm}$, sendo o volume médio de mel armazenado de $15,85 \mathrm{~mL}$; altura e diâmetro médios dos potes de pólen de $3,21 \mathrm{~cm}$ e $2,93 \mathrm{~cm}$, enquanto a massa média de pólen depositado foi de 12,56 g. A população variou de 3537 a 10281 indivíduos entre as colônias. Os resultados sugerem que a conservação de $M$. mondury deve envolver o reflorestamento com espécies nativas da Mata Atlântica; e as dimensões das caixas racionais foram definidas com base no tamanho médio dos ninhos no ambiente natural, para subsidiar estratégias conservacionistas e de manejo racional.

Palavras-chave: Abelhas sem ferrão, arquitetura do ninho, conservação, manejo racional, substrato de nidificação. 


\section{Introduction}

The tribe Meliponini, which includes the "indigenous stingless bees" is widespread over tropical regions worldwide and subtropical areas of South hemisphere. Brazil encompasses most of their occurrence, comprising nearly 375 eusocial species distributed into 23 genera (Camargo \& Pedro, 2013).

The meliponini species show a large array of nesting and nest thermoregulation strategies. One of these strategies is the nesting within trunk cavities with thick walls and construction of involucrum around broods (Nogueira-Neto 2002, Cortopassi-Laurindo \& Nogueira-Neto 2003). The indigenous stingless bees are remarkable pollinators, being responsible for $30 \%$ to $40 \%$ of pollination rate according to biomes (Kerr 1997). Therefore, they directly improve the production of fruits and seeds that are used as resources for several species (Silveira et al. 2002), including humans.

Independently of the Brazilian region, forests are the most suitable location for meliponins finding food and nesting places. However, these environments have been changing over the years by human action and nowadays are severely fragmented. This process threatens the regional biodiversity because of isolation of remaining populations, leading to losses in genetic variation, one of the main causes of species extinction (Schaffer \& Prochnow 2002).

Deforestation reduces the population of stingless bees, particularly in areas used for intensive agriculture and cattle production inasmuch these disturbed areas acts as barriers to fixation and dispersal of species that depend on specific vegetation types (Kerr 1987,Viana \& Melo 1987).

Within meliponins, Melipona Illiger, 1806 is the most species-rich genus (nearly 70 representatives) with distribution throughout the Neotropical region, from Mexico to Misiones in Argentina, and higher diversification in Amazon basin (Silveira et al. 2002, Camargo \& Pedro, 2013). Melipona mondury Smith 1863, popularly known as "uruçu amarela" is an efficient producer of honey and pollen, playing a major role in pollination and primary environmental services. It is found in Atlantic Forest fragments from the states of Bahia, Espírito Santo, Rio de Janeiro, Minas Gerais, São Paulo, Paraná and Santa Catarina (Melo 2003), and its rational culture might determine both economic and environmental advantages.

The knowledge about nesting habits of stingless bees such as M. mondury allows understanding their adaptation to habitats (Alfaro 2003) and helps the establishment of strategies of forest management to conservation of species. This information is also useful to improve the management practices and increase the productivity of rational colonies, an economic activity with low environmental impacts and related to familiar agriculture.

However, studies about the nest biology of this species are not available. Therefore, the goal of this work was to investigate the nesting substrate and bionomic features including population density of colonies of Melipona mondury, through the nest architecture analysis of colonies in nature and in rational boxes, as a support to conservation of the species and the rational creation.

\section{Material and methods}

The present study comprised 19 colonies of M. mondury in Atlantic Forest, being 13 raised in boxes and six in natural beehives (isolated trunk cavities kept in culture systems), in the

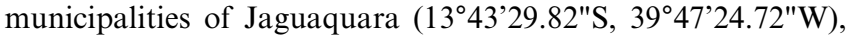
Jequié $\left(13^{\circ} 51^{\prime} 4^{\prime \prime} \mathrm{S} / 40^{\circ} 04^{\prime} 52^{\prime \prime} \mathrm{W}\right)$ and Tancredo Neves $\left(13^{\circ}\right.$ $\left.27^{\prime} 14^{\prime \prime S} / 39^{\circ} 25^{\prime} 15^{\prime \prime W}\right)$ (Bahia/Brazil) from December 2009 to August 2011.

The nest description was performed according to the methodology proposed by Camargo (1970) and Wille \& Michener (1973). The following indicators were analyzed:

- Substrate used for nesting of colonies in natural beehives length of trunk cavity, diameter of trunk cavity, wood thickness;

- Nest features - volume of trunk cavity occupied by colony (L) (in beehive), height of brood area $(\mathrm{cm})$, number of brood combs, length and width of brood combs $(\mathrm{cm})$, diameter of entrance hole $(\mathrm{mm})$, height and diameter of brood combs $(\mathrm{mm})$, height of pillars $(\mathrm{cm})$, height and diameter of honey pots $(\mathrm{cm})$, volume of honey pots $(\mathrm{ml})$, height and diameter of pollen pots $(\mathrm{cm})$, mass of pollen in closed pots $(\mathrm{g})$;

- Bee population - number and mass of specimens per colony, number of brood cells per $\mathrm{cm}^{2}$ of comb.

The external measurements of length and diameter in trunk cavity and wood thickness of substrate used for nesting were obtained by using a tape measure. A pachymeter and a ruler were used to obtain the length, width and diameter of nest features. A disposable 20-mL syringe was used to collect the content of honey pots and measure their volume. The mass of pollen stored in pots was determined by using a digital scale (precision of $0.01 \mathrm{~g}$ ). The weight of workers and queen bee was obtained in an analytical scale model Denver Instrument APX-200 (precision of $0.001 \mathrm{~g}$ ).

The mean number of brood cells per $\mathrm{cm}^{2}$ of comb and the state of colonies were obtained according to Aidar (1995). The total population was estimated as proposed by Ihering (1930) based on the ratio $(x+x / 2)$, where $x$ is the total number of brood cells in a colony. The vegetal species used as beehives were identified by taxonomists and confirmed by comparing them with exsiccates sent to the herbarium at UESB (Universidade Estadual do Sudoeste da Bahia).

After describing the nest architecture, the colonies were transferred to $20 \times 20 \times 20 \mathrm{~cm}$ boxes model INPA (Oliveira \& Kerr 2000) to nest and overnest, adequate to management and artificial development of colonies of $M$. mondury, as previously determined. The temperature inside colonies and involucre in boxes were obtained by using a digital thermo-hygrometer JProlab indoor/outdoor.

The data analysis was carried out using the software BioEstat version 5.0 (Ayres et al. 2007), which as based on the descriptive analysis of variables by estimating mean, standard deviation and variation coefficient. Moreover, the relationship between environmental, colony and involucre temperature around brood areas was evaluated by Pearson's linear correlation.

\section{Results}

Two out of the six colonies of $M$. mondury found nesting in natural substrate used the tree Pouteria venosa (Mart.) Baehni (Sapotaceae) while the others nested in different species, identified as Hirtella hebeclada Moric. ex DC (Chrysobalanaceae), Tabebuia serratifolia (Vahl) Nichols (Bignoniaceae), Ocotea 
Table 1. Results of measurements recorded in M. mondury nesting substrates.

Tabela 1. Resultados das medidas registradas nos substratos de nidificação de $M$. mondury.

\begin{tabular}{lccrr}
\hline Measures & Min & Max & Mean & SD \\
\hline Cavity length of the tree trunk (cm) & 80 & 110 & 93 & 12 \\
Cavity diameter trunk (cm) & 11 & 19 & 16 & 3 \\
Wood thickness (cm) & 4 & 12 & 7 & 3 \\
Cavity volume of the trunk (L) & 10 & 24 & 18,4 & 5 \\
\hline
\end{tabular}

odorifera (Vellozo) Rohwer (Lauraceae) and Byrsonima stipulacea A.Juss. (Malpighiaceae). The nests of M. mondury were found in relatively preserved Atlantic Forest areas within large fragments and the bees visited vegetal species in advanced successional steps.

The mean volume and diameter of trunk cavities used as nests by $M$. mondury were equal to $18.4 \pm 5.34 \mathrm{~L}$ and $15.8 \pm$ $2.95 \mathrm{~cm}$, respectively. The wood thickness ranged from 4 to 12 $\mathrm{cm}$, with a mean value of $7.0 \pm 3.0 \mathrm{~cm}$ (Table 1). The entrance hole in colonies of $M$. mondury presented a mean diameter of $0.96 \pm 0.14 \mathrm{~cm}$, and the height in relation to soil ranged from 2.80 to $5.20 \mathrm{~m}$.

In all studied colonies of $M$. mondury, involucres were observed around brood combs, being thicker in less populated colonies. During warmer seasons, the nest of hives transferred to boxes remained without involucrum for longer periods when compared the periods of lower temperatures (around $22^{\circ} \mathrm{C}$ ), when the involucres started being built right after nest transference.

The temperature of brood combs in colonies ranged from 28 to $31^{\circ} \mathrm{C}$ with a mean value of $29.67 \pm 0.33{ }^{\circ} \mathrm{C}$ while the environmental temperature during studied period varied from 17 to $30{ }^{\circ} \mathrm{C}$, with a mean value of $22.58 \pm 1.16{ }^{\circ} \mathrm{C}$. The temperature range in the environment was equal to $13^{\circ} \mathrm{C}$, while that within brood combs was equal to $3^{\circ} \mathrm{C}$.

No significant correlation between environmental and involucrum temperature was detected in the most populated colony established in box $\left(p=0.1176, r=0.48\right.$ and $\left.r^{2}=23 \%\right)$. However, a significant correlation $(\mathrm{p}<0.01)$ was observed between environmental and within-colony temperatures $(\mathrm{r}=0.85$ and $\mathrm{r}^{2}=72.1 \%$ ).

In less populated colonies, the correlation was positive and significant for both environmental and honey pot temperature and environmental and within-colony temperature $(\mathrm{p}<0.01)$, as shown by the high values of correlation (r) and determination $\left(\mathrm{r}^{2}\right)$ coefficients.

The number of brood combs in colonies of M. mondury ranged from six to $15($ mean $=9.26 \pm 2.64)$. The mean dimensions of brood combs were $12.03 \pm 3.89 \mathrm{~cm}$ in length, $9.75 \pm 3.33 \mathrm{~cm}$ in width, $10.03 \pm 0.18 \mathrm{~mm}$ in height, $0.52 \mathrm{~cm}$ of internal diameter and $3.75 \pm 0.62$ cells $/ \mathrm{cm}^{2}$. The combs were separated from each other by wax pillars of $0.41 \pm 0.05 \mathrm{~cm}$ in average height, allowing the bees to pass between brood disks. The arrangement of brood combs varied among colonies, being either helicoidal or overlapped. In Table 2, the bionomic measurements reported for $M$. mondury are compared to other Melipona species.

The measurements of honey pots of $M$. mondury ranged from 2 to $5 \mathrm{~cm}$ in diameter $($ mean $=2.81 \pm 0.54 \mathrm{~cm}) ; 2$ to $4 \mathrm{~cm}$ in height $($ mean $=3.29 \pm 0.54 \mathrm{~cm})$; and 7 to $39 \mathrm{~mL}$ of stored honey volume $($ mean $=15.85 \pm 5.30 \mathrm{~mL})$. The dimensions of pollen pots ranged from 2 to $4 \mathrm{~cm}$ (mean value of $2.93 \pm 0.58$ $\mathrm{cm}$ ) in diameter, and 2 to $7 \mathrm{~cm}$ in height (mean of $3.21 \pm 0.81$ $\mathrm{cm})$. The pollen mass deposited in closed pots varied from 5 to $33 \mathrm{~g}$ (mean of $12.56 \pm 4.93 \mathrm{~g}$ ) (Table 3). In Table 2, a comparison of measurements of honey and pollen pots among different Melipona species is presented.

The storage capacity of honey and pollen pots among developed colonies in hives and boxes had no significant differences $(p=0.4716)$. Similarly, the volume of honey and pollen mass in pots between hives and boxes were equivalent $(\mathrm{p}=0.4716)$.

Taking into account the mean number of brood cells per colony, the population of M. mondury varied from 3537 to 10281 individuals, including eggs, larvae, pupae and adults (mean of $5959 \pm 1736$ individuals). In this work, colonies raised in 16-L boxes had some empty spaces and mean individual number lower than that observed in natural hives. The comparison between mean number of individuals between colonies in hives and boxes revealed significant differences $(p<0.01)$. Table 4 shows the comparative data of number of individuals per colony observed in this study for $M$. mondury and previous reports in other congeners.

The mean number of individuals per colony was higher in hives (7762.83) when compared to boxes (5126.40), with significant differences $(\mathrm{p}<0.01)$.

\section{Discussion}

\section{Nesting substrate}

Similarly to the results observed in this work for M. mondury, Siqueira et al. (2007) also reported Melipona rufiventris Lepeletier, 1836 in trunk holes of trees belonging to genera Pouteria (Pouteria ramiflora (Mart.) Radlk, Sapotaceae) and Tabebuia (Tabebuia aurea (Manso) Benth. \& Hook.f., Bignoniaceae) along forest fragments in a transition zone

Table 2. Features of nests of Melipona mondury in relation to congeneric species.

Tabela 2. Características dos ninhos de Melipona mondury em relação aos ninhos de espécies congêneres.

\begin{tabular}{|c|c|c|c|c|c|c|c|c|}
\hline \multirow[b]{2}{*}{ Species } & \multicolumn{3}{|c|}{ Brood combs per colony } & \multicolumn{3}{|c|}{ Brood combs } & \multirow{2}{*}{$\frac{\text { Pillars }}{\text { Height }}$} & \multirow[b]{2}{*}{ Reference } \\
\hline & Number & Length (cm) & Width (cm) & Per $\mathrm{cm}^{2}$ & Height (cm) & Diameter (cm) & & \\
\hline M. mondury & 9.26 & 12.03 & 9.75 & 3.75 & 1.00 & 0.52 & 0.41 & This study \\
\hline M. mandacaia & 6.13 & 6.32 & 5.74 & 4.23 & 1.01 & 0.57 & 0.7 & Alves et al. (2007) \\
\hline M. alsilvai & 5.55 & 5.44 & 4.13 & 5.87 & 0.76 & 0.45 & 0.4 & Souza et al. (2008) \\
\hline M. scutellaris & 6.81 & 9.33 & 8.63 & & & & & Alves et al. (2012) \\
\hline M. quadrifasciata & 5.1 & & 5.8 & & & & & Brito et al. (2013) \\
\hline M. compressipes & 6.6 & 11.2 & 7.4 & & & & & Almendra (2007) \\
\hline
\end{tabular}


Viana, J.L. et al.

Table 3. Comparison of honey and pollen pots of different Melipona species.

Tabela 3. Comparação das medidas dos potes de mel e de pólen entre diferentes espécies do gênero Melipona.

\begin{tabular}{|c|c|c|c|c|c|c|c|}
\hline & \multicolumn{3}{|c|}{ Honey pots } & \multicolumn{3}{|c|}{ Pollen pots } & \multirow[b]{2}{*}{ Reference } \\
\hline & Diameter (cm) & Height (cm) & Volume (mL) & Diameter (cm) & Height (cm) & Mass (g) & \\
\hline M. mondury & 2.81 & 3.29 & 15.85 & 2.93 & 3.21 & 12.56 & This study \\
\hline M. mandacaia & 2.53 & 2.78 & 6.47 & 2.48 & 3.02 & 6.66 & Alves et al. (2007) \\
\hline M. alsilvai & 2.03 & 2.4 & 4.1 & 2.28 & 2.67 & 4.46 & Souza et al. (2008) \\
\hline M. scutellaris & & & 15.71 & & & 14.04 & Alves et al. (2012) \\
\hline M. quadrifasciata & & & 5.73 & & & & Brito et al. (2013) \\
\hline M. compressipes & 2.9 & 3.7 & 15.8 & 2.8 & 3.5 & 14.1 & Almendra (2007) \\
\hline
\end{tabular}

between Brazilian savannah and semi deciduous seasonal forest of Minas Gerais, as well as in species of other genera. Pouteria ("abiu") is a fruit plant and Tabebuia ("ipê") is used in landscaping and furniture industry.

$M$. mondury is genetically close to $M$. rufiventris that occurs in Brazilian savannah (cerrado). Moure (1975) was the first to propose that individuals from Atlantic forest were morphologically distinguished from those found in "Cerrado". Therefore, $M$. rufiventris and $M$. mondury were valid species names from populations from Cerrado and Atlantic forest regions, respectively (Obiols 2008, Camargo \& Pedro 2013). Molecular studies using PCR-RAPD (Tavares et al. 2008), microsatellite (Lopes 2004, Tavares et al. 2008), PCR-RFLP (Schetino 2005, Barni et al. 2007), isozymes (Tavares et al. 2008) and ISSR (Dias 2008) markers corroborated the differences pointed out by Melo (2003) and Moure (1975).

Souza et al. (2008), analyzing bionomic features of Melipona asilvai Moure, 1971 observed individuals of that species nesting in umburana (Amburana cearenses Smith, Fabaceae), a species usually regarded as a suitable substratum for stingless bees, particularly Melipona subnitida Ducke, 1910 (Bruening 1990). Mesquite (Prosopis juliflora (sw.) DC., Fabaceae) was the second species with the highest number of nests.

Alves et al. (2007) reported 15 colonies of Melipona mandacaia Smith, 1863 in "umburana-de-cambão" (Commiphora leptophloeos (Mart.) Gillett (Burseraceae)), while Oliveira (2002) found M. mandacaia nesting in "quixabeira" (Sideroxylon obtusifolium Roem. \& Schult.). Both botanical species occurring in the "Caatinga" biome. These plant species are of beekeeping and medicinal importance, and are threatened by deforestation.

When compared to M. mondury, other intensively studied species of Melipona from drier regions, such as M. mandacaia
Smith, 1863, M. quadrifasciata Lepetier, 1836 and M. subnitida Ducke, 1910, nested mostly in certain vegetal species like Centrolobium tomentosum Guill. ex Benth. (Alves et al. 2007).

The present results in $M$. mondury suggest this species has adapted to different substrata because of the higher floristic diversity within their range and a lower concentration of specific tree species per area, thus differing from the conditions reported by Souza et al. (2008) and Alves et al. (2007) for M. asilvai and M. mandacaia, respectively. Alves et al. (2009) observed that M. scutellaris Latreille, 1811 nests in an array of substrata since 82 nests were observed in 19 vegetal species from 12 families.

According to Araújo et al. (1998), M. mondury occurs in moist forests with the presence of tall trees such as Dalbergia nigra, Caesalpinia echinata and Cariniana sp., and the abundance of epiphytes, differing from the area occupied by M. scutellaris. M. mondury occurs in an environment with greater diversity of plant species and lower concentrations of the same species per area, while M. scutellaris is found in domain of lower diversity and higher concentration of the same species, such as Sclerolobium sp. and Tapirira sp., which are excellent substrates for nesting.

Cortopassi-Laurino et al. (2009), studying neotropical trees used for nesting by stingless bees revealed that Fabaceae and Anacardiaceae were the most observed families with nests of Meliponini, including Melipona. Under natural conditions, M. mondury, a stingless bee species from Atlantic forest, occupies holes formed by natural accidents in trees in which the poor healing allows the entrance of water into the trunk, thus accelerating the deterioration of lignified parts and forming a favorable place for nesting. Once most species of Meliponini build nests in trunk cavities, strategies to maintain their biodiversity should include vegetal species that usually form trunk holes.

Table 4. Number of individuals per colony of M. mondury in relation to other Melipona species.

Tabela 4. Número de indivíduos por colônia de $M$. mondury em comparação aos de outras espécies de Melipona.

\begin{tabular}{|c|c|c|c|c|c|}
\hline & \multicolumn{4}{|c|}{ Number of specimens per colony } & \multirow[b]{2}{*}{ Reference } \\
\hline & Min & $\operatorname{Max}$ & Mean & Deviation & \\
\hline M. mondury & 3537 & 10281 & 5959 & 1736 & This study \\
\hline M. mandacaia & 889 & 1597 & 1297 & & Alves et al. (2007) \\
\hline M. alsilvai & & 1868 & 1034 & & Souza et al. (2008) \\
\hline M. scutellaris & 1315 & 3945 & 2485 & 515.19 & Alves et al. (2010) \\
\hline M. quadrifasciata & & & 1092 & 338.37 & Brito et al. (2013) \\
\hline M. compressipes & & & 2079 & & Almendra (2007) \\
\hline
\end{tabular}


The mean volume of trunk cavities used as nests by $M$. mondury (Table 1) was higher to the mean volume of nest cavities in M. mandacaia, reported by Alves et al. (2007), of $1.59 \mathrm{~L}$; and $2.73 \mathrm{~L}$ by $M$. asilvai, according to Souza et al. (2008), what might indicate the potential of this species to the productions of individuals, pollen and honey.

The mean diameter of trunk cavity in nest cavities of M. mondury $(15.8 \pm 2.95 \mathrm{~cm})$ was also higher than that observed in trunks of trees from drier regions inhabited by M. mandacaia (mean diameter of $7.15 \pm 1.17 \mathrm{~cm}$ ) (Alves et al. 2007) and M. asilvai (mean diameter of $6.77 \pm 1.9 \mathrm{~cm}$ ) (Souza et al. 2008). According to Siqueira et al. (2007), the timber extraction of trees with large diameter might lead to scarcity of nesting substrata.

The mean thickness of wood in nests of $M$. mondury was similar to the mean value of $6.86 \mathrm{~cm}$ for trunks with nests of M. mandacaia (Alves et al. 2007) and $6.78 \mathrm{~cm}$ for $M$. asilvai (Souza et al. 2008). The mean length of trunk cavity in these congeners was also similar: $92.6 \pm 12.4 \mathrm{~cm}$ for $M$. mondury (this study), $115 \pm 20.28$ for M. mandacaia (Alves et al. 2007) and $96 \pm 25$ for $M$. asilvai (Souza et al. 2008). Therefore, the conservation of flora visited by $M$. mondury will also contribute to the protection of other species of Melipona that coexist in the same region.

\section{Nest architecture}

2.1 Colony entrance. The construction of colony entrance to protect against invaders, location and landing by Melipona mondury is made of clay, wax, resin and propolis, composing the geopropolis of hard density and red coloration, forming a central orifice surrounded by convergent rays, detached in populated colonies with a coloration that might change according to the pigment of used resin.

The glandular substances applied to the structure of colony entrance serve to guide the foragers because of their high reflectivity to ultraviolet light (Ihering 1930, Roubik 1989). Nonetheless, in the case of $M$. mondury, the entrance of colonies become overcrowded during periods of high foraging since the orifice presents a reduced diameter when compared to body size, allowing the entrance of a single bee each time. It was observed a forager that guards the orifice in structure entrance, aware of any intruder.

Alves et al. (2007) reported a mean diameter of $0.71 \mathrm{~cm}$ for the entrance orifice in nests of $M$. mandacaia. In $M$. asilvai, Souza et al. (2008) reported a mean diameter of entrance orifice equal to $0.36 \mathrm{~cm}$. These and other authors (Nogueira Neto 1997, Oliveira 2002, Souza et al. 2008) observed that, in less populated colonies of some Melipona species ( $M$. mandacaia, M. quadrifasciata, M. subnitida and M. asilvai), the bees close the entrance orifice with clay and/or animal feces during period of low temperature or dry season (Alves et al. 2007, Nogueira Neto 1997, Oliveira 2002, Souza et al. 2008). This behavior was absent in $M$. mondury. The population of $M$. mondury varied between 3537 and 10281 individuals (eggs, larvae, pupae and adults) being the mean value of $5959 \pm 1736$ individuals.

2.2 Presence of involucre and thermoregulation. The involucres in colonies of M. mondury are related to thermoregulation of brood combs. The mode of involucrum production by M. mondury is similar to that described by Alves et al. (2007) and Souza et al. (2008) in M. mandacaia and M. asilvai, respectively. Alves et al. (2007) observed that only few colonies of $M$. mandacaia presented this structure. However, in colder regions, even highly populated colonies of $M$. mondury had involucres. Therefore, the presence of involucrum is more related to environmental temperature than to activity level of colonies.

The results of this study suggest that thermoregulation is more efficient in the presence of wax lamellae in involucres and populations of high density, as observed by Nogueira-Neto (2002); Cortopassi-Laurino (2003). This can be one of the reasons that hinder the survival of less populated colonies during colder seasons, when the temperature in the brood combs remains below the mean value of $29.67^{\circ} \mathrm{C}$, verified in dense colonies.

2.3 Brood combs. The measurements of brood combs were remarkably higher in $M$. mondury when compared to other species of Melipona. In M. mandacaia, Alves et al. (2007) estimated a mean value of 6.13 combs per colony with dimensions of $6.32 \mathrm{~cm}$ in length and $5.74 \mathrm{~cm}$ in width, slightly shorter than the mean values reported in $M$. mondury. Similarly, Souza et al. (2008), analyzing nests of $M$. asilvai, found on average 5.55 combs per colony being $5.44 \mathrm{~cm}$ long and $4.13 \mathrm{~cm}$ wide. Studies carried out by Brito et al. (2013) and Almendra (2007), the indicators of brood combs for M. quadrifasciata and M. compressipes Schwarz, 1932, respectively, were also inferior to those observed in $M$. mondury. The results regarding the brood cells were similar to the reports by Alves et al. (2007) in M. mandacaia and Souza et al. (2008) in M. asilvai (Table 2).

2.4 Food pots. The pollen and honey pots were overlapped and attached to nest walls by wax pillars similar to those separating

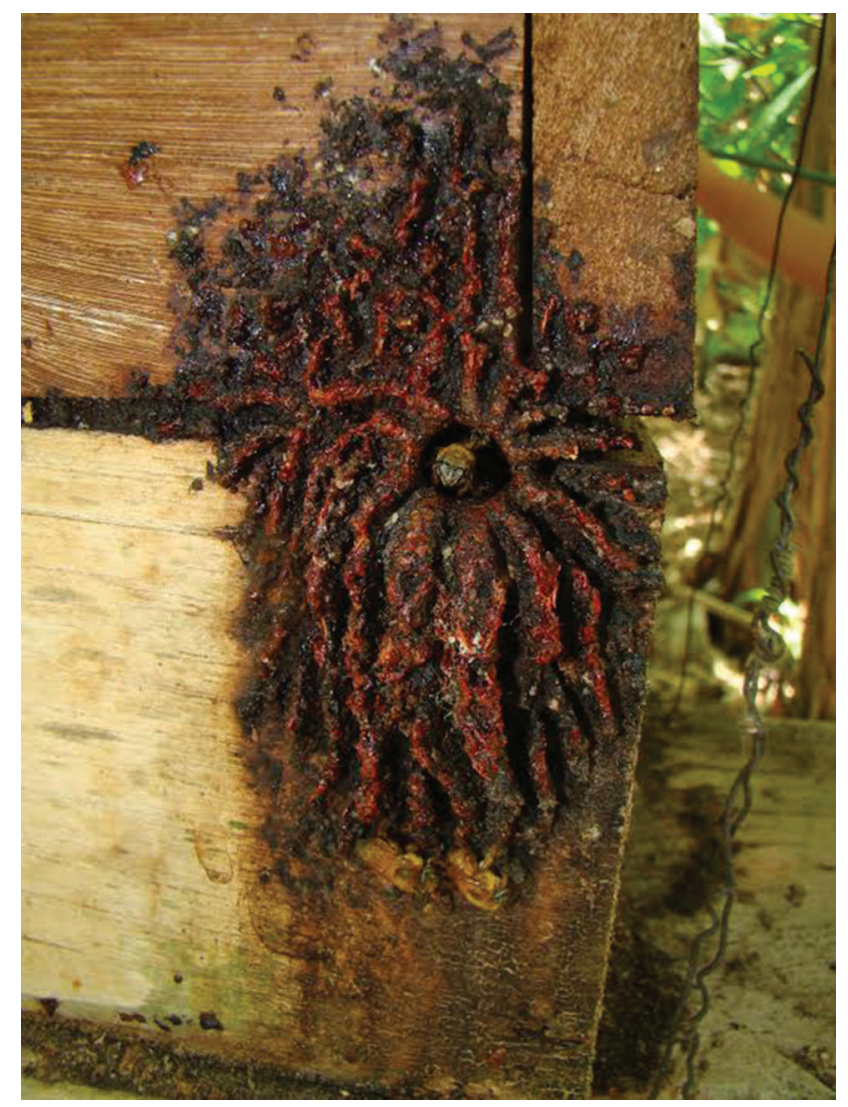

Figure 1. Colony entrance of Melipona mondury.

Figura 1. Entrada da colônia de Melipona mondury. 


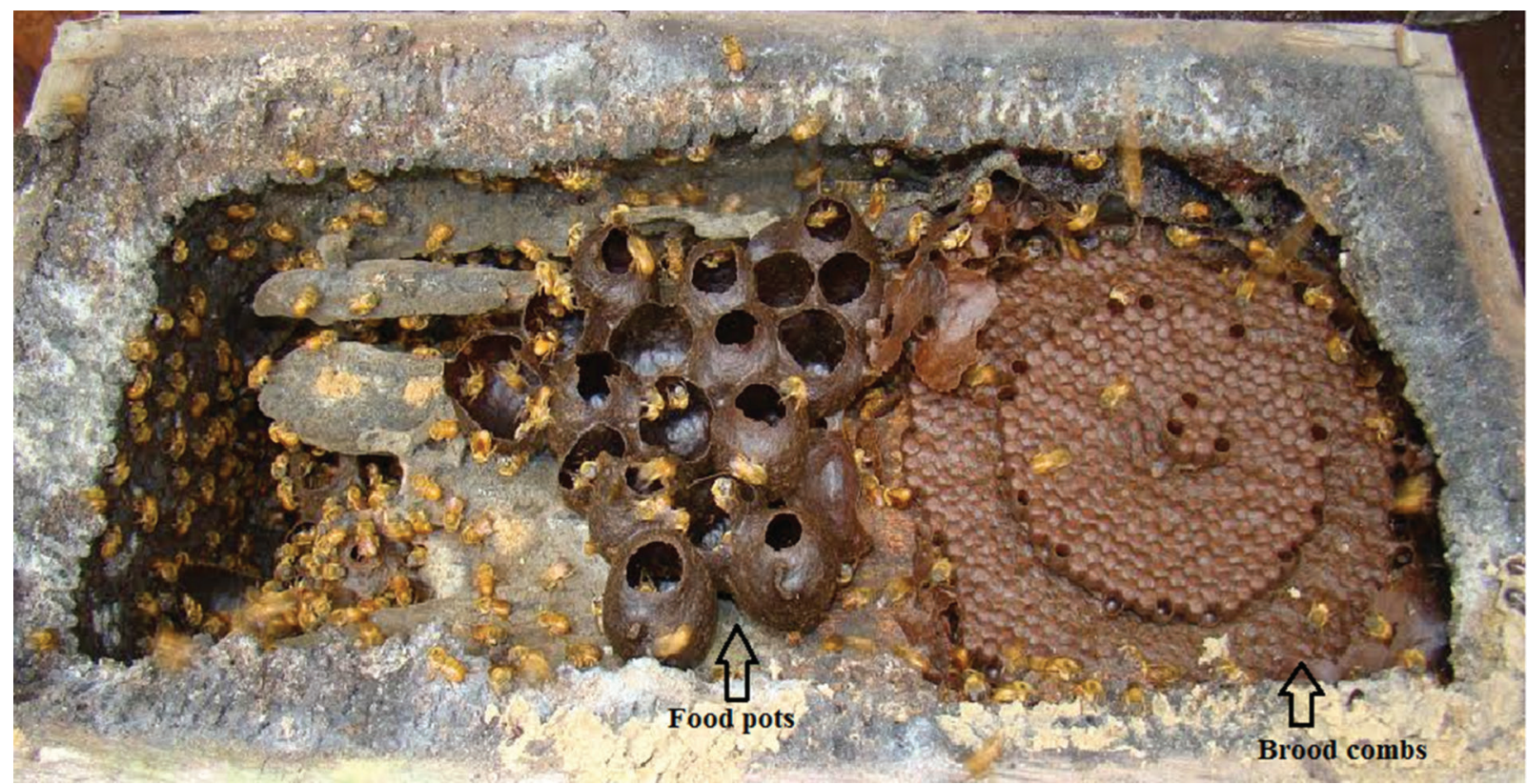

Figure 2. Rational box with honey and pollen pots and brood combs of Melipona mondury.

Figura 2. Caixas racionais com potes de mel e de polén e discos de cria de Melipona mondury.

the combs. Souza et al. (2008) reported the same irregularity in organization of honey and pollen pots in $M$. asilvai. In several meliponins, this irregular shape in both dimensions and organization is influenced by the space to nesting, once workers are likely to occupy most of available space (Camargo 1970). The number of pollen and honey pots were 129 and 82 respectively.

According to Table 3, both diameter and height of honey pots are similar among species, while the honey volume in pots showed a greater variation. The volume of honey in pots of $M$. mondury was similar to that reported in M. scutellaris and M. compressipes.

\section{Population Estimation}

The variation in the number of individuals per colony in a same species is also reported in other Melipona species. Alves et al. (2007) found 1297 individuals on average for M. mandacaia, ranging from 889 to 1597 . Souza et al. (2008) obtained similar results in $M$. asilvai, with a mean number of 1034 individuals while the most populated colony had 1868 individuals. The most numerous populations of $M$. mondury when compared to other species (Table 4) might represent an advantage for the commercial raising of this species, since a higher number of foragers will determine more efficient foraging and flower visitation. Consequently, this could favor the production of honey, pollen, or even the success of pollination projects.

The higher incidence of empty spaces and the lower mean number of individuals in boxes in relation to natural hives are expected since the food supply for colonies in natural environments is higher. Considering that colonies from each substratum were located close to each other, this difference should not be related to features like differential competition by resources between both nest types but rather to lack of manipulation in hives, thereby avoiding stress caused by management of bees. In hives, the colonies are less susceptible to frequent handling by bee keepers that might damage the nests and demand additional efforts in workers to rebuild them.

The conservation status of M. mondury is heterogeneous throughout their natural range and its occurrence is presently limited to forest fragments. The conservation of this species should encompass the reforestation of Atlantic Forest with native and regional species, including those plants used for nesting and resin collection by the colonies investigated in the present work, once $M$. mondury is usually found in large and high-quality fragments. The inclusion of vegetal species pollinated by stingless bees of the genus Melipona in reforestation programs is highly recommended. This study suggests that the dimensions of boxes in $M$. mondury should be defined based on the mean size of nests found in natural habitat, as well as the food availability (pollen and nectar) around the location of meliponaries. In this context, studies about bionomics are particularly relevant, once these data might be useful to the rationale management and species conservation, like $M$. mondury, that might serve as income sources for local farmers throughout their range.

\section{Acknowledgments}

The authors are grateful to Fundação de Amparo à Pesquisa do Estado da Bahia (FAPESB) and Universidade Estadual do Sudoeste da Bahia (UESB) for financial support.

\section{References}

AIDAR, D.S. 1995. Multiplicação artificial e manejo de colônias de Melipona quadrifascia Lep. (Hymenoptera, Apidae, Meliponinae). Tese de Doutorado. Universidade Federal de Viçosa. 85 p.

ALFARO, M.Y.C. 2003. Comparacion de nidos de abejasinaguijón em três regiones de Guatemala. Available in http://www.monografias. com/trabajos7/abag/abag.shtml?relacionados Assessed in March 23rd 2014. 
ALMENDRA, E. C. A. 2007. Aspectos da bionomia da abelha tiúba (Melipona compressipes) / Eline Chaves de Abreu Almendra, Teresina, 2007. 53 f. Dissertação (Mestrado em Ciência Animal) Universidade Federal do Piauí. 2007.

ALVES, R.M.O., SOUZA, B.A. \& CARVALHO, C.A.L. 2007. Nota sobre a Bionomia de Melipona mandacaia (APIDAE: MELIPONINA). Magistra, 19 (3) 204-212.

ALVES, R.M.O., SOUZA, B.A., CARVALHO, C.A.L., SOUZA, L.S.S. \& ANDRADE, J.P. 2009. Substratos vegetais utilizados para nidificação pela Abelha uruçu (Melipona scutellaris) no litoral norte do Estado da Bahia. Mensagem doce $n^{\circ} 100$. Março de 2009. Available in http://www.apacame.org.br/mensagemdoce/ 100/msg100.htm. Assessed in March 23rd 2014.

ALVES, R.M. de O.; CARVALHO, C. A. L. de; FAQUINELlO, P.; LÊDO, C.A. da S.; FIGUEREDO, L. 2012. Parâmetros biométricos e produtivos de colônias de Melipona scutellaris Latreille, 1811 (Hymenoptera: Apidae) em diferentes gerações. Magistra 24: 105-111.

AYRES, M., AYRES Jr, M., AYRES, D.L. \& SANTOS, A.A. 2007. BioEstat: aplicações estatísticas nas áreas das ciências biológicas e médicas. Belém; Sociedade Civil Mamirauá: MCT-CNPq, 2007.

BARNI, G. S., STRAPAZZON, R., GERRA, J.V.C. \& MORETTO, G. 2007. Mitochondrial genome diferences between the stingless bees Melipona rufiventris and Melipona mondury (Apidae: Meliponini). Genetics and Molecular Research 6 (1): 8-14.

BRITO, B.B.P., FAQUINELlO, P., PAULA-LEITE, M.C. \& CARVALHO, C.A.L. 2013. Parâmetros biométricos e produtivos de colônias em gerações de Melipona quadrifasciata anthidioides. Archivos de Zootecnia 62 (238): 265-273. 2013, http://dx.doi.org/ 10.4321/S0004-05922013000200012.

BRUENING, H. 1990. Abelha jandaíra. Coleção Mossoroense, série C, volume 557. $181 \mathrm{p}$.

CAMARGO, J.M.F. 1970. Ninhos e biologias de algumas espécies de Meliponideos (Hymenoptera: Apidae) da região de Porto Velho, Território de Rondônia, Brasil. Revista de Biología Tropical 16: 207-239.

CAMARGO J. M F. \& PEDRO, S. R M. 2013. Meliponini Lepeletier, 1836. In Moure, J. S., Urban, D. \& Melo, G. A. R. (Orgs). Catalogue of Bees (Hymenoptera, Apoidea) in the Neotropical Region - online version. Available at http://www.moure.cria.org.br/ catalogue. Accessed Sep/25/2014

CORTOPASSI-LAURINO, M. \& NOGUEIRA-NETO P. 2003. Notas sobre bionomia de Tetragonisca weyrauchi Schwwarz, 1943 (Apidae, Meliponini). Acta Amazonica 33: 643-650.

CORTOPASSI-LAURINO, M., ALVEZ, D.A. \& IMPERATRIZFONSECA, V.L. 2009. Árvores neotropicais, recursos importantes para a nidificação de abelhas sem ferrão (Apidae, Meliponini). Mensagem Doce $n^{\circ} 100$. Março de 2009. Available in http://www.apacame. org.br/mensagemdoce/100/artigo9.htm. Assessed in March 23rd 2014.

DIAS, F. G. 2008. Diferenciação genética entre Melipona mondury, Smith, 1863, Melipona rufiventris, Lepeletier, 1836 e Melipona sp. (Hymenoptera, Apidae) no Estado de Minas Gerais, Brasil, utilizando marcadores moleculares ISSR. Dissertação de Mestrado Universidade Federal de Viçosa. Viçosa, 2008.

IHERING, H. 1930. Biologia das abelhas melíferas do Brasil. Publicado em 1930, como tradução do original alemão impresso em 1903. Tradutores: R.vonIhering e B. Correia de Sampaio. Boletim de Agricultura da Secretaria de Agricultura do Estado de São Paulo. 31 (5-8): 435-506, 649-714.

KERR, W.E. 1987. Biologia, manejo e genética de Melipona compressipes fasciculataSmith (Hymenoptera, Apoidea). Tese de Professor Titular. UFMA - Universidade Federal do Maranhão. São Luis, Brasil, 141p.
KERR, W.E. 1997. Importância da meliponicultura para o país. Biotecnologia Ciência e Desenvolvimento, 1 (3):42-44.

LOPES, D. M. 2004. Diversidade e estrutura genética em populações de Melipona rufiventrise Melipona mondury (Hymenoptera: Apidae) por análise de microssatélites. Dissertação de Mestrado Universidade Federal de Viçosa. Viçosa.

MELO, C.A.R. 2003. Notas sobre meliponíneos neotropicais (Hymenoptera, Apoidae). Com a descrição de três novas espécies. In: Apoidea Neotropical. Homenagem aos 90 anos de Jesus Santiago Moure. UNESC. Santa Catarina, Brasil. p.85-92.

MICHENER, C. D. 2000. The Bees of the World.Baltimore. Johns Hopkins. Nature - 953p.

NOGUEIRA-NETO, P. 1997. Vida e criação de abelhas indígenas sem ferrão. Editora Nogueirapis. São Paulo. 445p.

NOGUEIRA-NETO, P. 2002. Management of Plants to Maintain and Study Pollinating Bee Species, and Also to Protect Vertebrate Frugivorous Fauna. IN: Kevan P \& Imperatriz Fonseca VL (eds) Pollinating Bees - The Conservation Link Between Agriculture and Nature - Ministry of Environment / Brasília. p.21-28.

OBIOLS, C. L.Y. 2008. O gênero Melipona Illiger, 1806 em Minas Gerais - identificação, distribuição e estado atual de conservação. Dissertação de Mestrado. PPG em Ecologia, Conservação e Manejo da Vida Silvestre. UFMG. 2008. 108 p.

OLIVEIRA, F. \& KERR, W.E. 2000. Divisão de uma colônia de jupará (Melipona compressipes manaosensis) usando-se a colméia e o método de Fernando Oliveira. INPA/MCT. Manaus. 10 p.

OLIVEIRA, C.M. 2002. Hábitos de nidificação de abelhas sem ferrão do gênero Melipona ILLIGER, 1806 (Hymenoptera; Apidae; Meliponinae) em áreas de caatinga do baixo-médio São Francisco. Universidade Estadual de Feira de Santana. Monografia. 32 p.

ROUBIK, D.W. 1989. Ecology and natural history of tropical bees. Cambridge Tropical Biology Series, $514 \mathrm{p}$.

SCHAFFER, W.B. \& PROCHNOW, M. 2002. A Mata Atlântica e você: como preservar, recuperar e se beneficiar da mais ameaçada floresta brasileira. Brasília: APREMAVI. 156p.

SCHETINO, M.A.A. 2005. Filogeografia de Melipona rufiventrise Melipona mondury: Contribuição para a elucidação do padrão de distribuição geográfico, inferências taxonômicas e preservação. Viçosa, MG: UFV. Monografia (Curso de Biologia) - Universidade Federal de Viçosa, Viçosa.

SILVEIRA, F.A., MELO, G.A.R. \& ALMEIDA, E.A.B. 2002. Abelhas brasileiras: sistemática e identificação. Belo Horizonte. 253p.

SIQUEIRA, E.L., MARTINES, R.B. \& NOGUEIRA-FERREIRA, F.H. 2007. Ninhos de abelhas sem ferrão (Hymenoptera, Meliponina) em uma Região do rio Araguari, Araguari-MG. Bioscience Journal, Uberlândia, 23, Supplement 1, 38-44.

SOUZA, B.A., ALVES, R.M.O. \& CARVALHO, C.A.L. 2008 Nota sobre a Bionomia de Melipona asilvai (Apidae: Meliponini) como subsídio à sua criação racional. Archivos de Zootecnia 57 (217): 53-62.

TAVARES, M.G., SALOMÃO, T.M.F., BORGES A.A. \& CAMPOS L.A.O. 2008. Uso de biologia molecular como subsídio para a preservação de abelhas: espécie do grupo rufiventris (Meliponini) em Minas Gerais. In: Vilela EF., Santos I A., Schoereder J H., Serrão J E., Campos L. A O. eds. Insetos Sociais: da biologia a aplicação. p128-141.

VIANA, L.S. \& MELO, G.A. 1987. Conservação de abelhas. Informe Agropecuário, Belo Horizonte, v. 13, n.149, p. 23-26.

WILLE, A. \& MICHENER, C.D. 1973. The nest architecture of stingless bees with special reference to those of Costa Rica (Hymenoptera: Apidae). Revista de Biologia Tropical 21: 1-278. 